\title{
Komparasi Aktivitas Tiga Jenis Asap Cair terhadap Pertumbuhan Mikroba secara In Vitro
}

\author{
(Comparison of the Three Types of Liquid Smoke Activity Against \\ Microbial Growth In Vitro)
}

\author{
Pasaribu T, Wina E \\ Balai Penelitian Pernak, PO Box 221, Ciawi, Bogor 16002 \\ pasaributiurma@yahoo.com
}

\begin{abstract}
Liquid smoke consists of phenols that have antimicrobial properties against bacteria Gram positive and Gram negative, yeast and fungi. Study was conducted to evaluate the antibacterial properties of cashew nut shell liquid smoke (ACM), corn cobs (ACJ), and coconut shell (ACK) against Escherichia coli and Candida utilis by using microplate reader. Each of blank, control, and sample consisted of four well (four times). Result showed that ACM (80.85\%) and the ACJ (72.34\%) was better in inhibiting the growth of E. coli than ACK (38.30\%). Meanwhile, the ACJ (97.17\%) and ACK $(86.80 \%)$ was better in inhibiting the growth of C. utilis than ACM $(23.88 \%)$. The higher the dilution of ACM, ACJ, and ACK the higher of the growth of $C$. utilis. The higher the content phenol of ACM, ACJ and ACK $(7,000 \mathrm{mg} / \mathrm{ml})$, the more increased the inhibitory on the growth of $C$. utilis $(86.80 \%)$. It was concluded that the ACM, ACJ, and ACK can suppress the growth of $E$. coli bacteria and fungi $C$. utilis. Therefore, they are potential as an antimicrobial.
\end{abstract}

Key Words: Antimicrobial, Liquid Smoke of Cashew Nuts Shell, Corn Cobs, Coconut Shells

\begin{abstract}
ABSTRAK
Asap cair memiliki sifat antimikroba terhadap berbagai bakteri Gram positif dan Gram negatif, ragi dan jamur karena kandungan fenolnya. Penelitian telah dilakukan untuk mengevaluasi aktivitas antibakteria dari asap cair cangkang jambu mete (ACM), tongkol jagung (ACJ) dan tempurung kelapa (ACK) terhadap Escherichia coli dan Candida utilis dengan menggunakan menggunakan microplate reader. Setiap blanko, kontrol dan sampel terdiri dari empat lubang (empat kali). Hasil penelitian menunjukkan bahwa ACM (80,85\%) dan ACJ $(72,34 \%)$ lebih baik dalam menghambat pertumbuhan E. coli dibandingkan dengan ACK $(38,30 \%)$. Sementara yang lebih baik menghambat $C$. utilis adalah ACJ $(97,17 \%)$ dan ACK $(86,80 \%)$ dibandingkan dengan ACM (23,88\%). Semakin tinggi pengenceran ACM, ACJ dan ACK maka pertumbuhan C. utilis semakin meningkat pula. Semakin tinggi $(7.000 \mathrm{mg} / \mathrm{ml})$ kandungan fenol dari ACM, ACJ dan ACK maka daya hambatnya terhadap pertumbuhan C. utilis semakin meningkat $(86,80 \%)$. Disimpulkan bahwa ACM, ACJ dan ACK dapat menekan pertumbuhan bakteri E. coli dan fungi $C$. utilis sehingga punya potensi sebagai antimikroba.
\end{abstract}

Kata Kunci: Antimikroba, Asap Cair, Cangkang Jambu Mete, Tongkol Jagung, Tempurung Kelapa

\section{PENDAHULUAN}

Asap cair dihasilkan dari proses pirolisis, yaitu dekomposisi bahan kimia organik melalui pembakaran langsung atau tidak langsung tanpa oksigen atau reagen lainnya. Pirolisis umumnya dilakukan pada bahan tanaman yang memiliki komposisi lignin, selulosa, hemiselulosa dan senyawa karbon lainnya (Darmadji 2002). Selama pembakaran akan terjadi proses pirolisis yang menghasilkan senyawa fenol, alkohol, karbonil, furan, lakton, hidrokarbon, polisiklik aromatik dan asam organik yang berperan dalam pemberian 
rasa, warna dan sifat antimikroba asap cair (Girrard 1992; Lingbeck et al. 2014). Penelitian asap cair dari berbagai bahan tanaman sudah banyak dilakukan dan digunakan sebagai antimikroba alami pada makanan. Pemanfaatan asap cair sebagai bahan aditif untuk bidang peternakan hanya sedikit yang telah dilaporkan. Pemberian asap cair lewat air minum hinga $1 \%$ dapat diberikan pada ayam broiler untuk mendapatkan karkas sehat dan hasil yang optimal pada sistem imun (Sari et al. 2014; Yosi \& Sandi 2014). Asap cair dari tempurung kelapa paling mudah diperoleh di Indonesia karena banyak usaha kecil pembuatan arang dari tempurung kelapa dan adanya permintaan asap cair dari tempurung kelapa untuk pengawet makanan (Rasydta 2013).

Tongkol jagung merupakan limbah dari perkebunan jagung yang banyak dimanfaatkan sebagai sumber serat pakan ruminansia. Program swasembada jagung dengan perluasan penanaman jagung, selain menghasilkan jagung pipilan untuk dikonsumsi manusia dan ternak, akan menghasilkan limbah tongkol jagung yang melimpah untuk dimanfaatkan menjadi produk baru selain sebagai sumber serat. Penelitian asap cair dari tongkol jagung telah dilaporkan oleh Swastawati et al. (2014) dan dimanfaatkan untuk pengawet ikan bandeng (Chanos chanos Forsk).

Cangkang jambu mete merupakan limbah dari industri kacang mete yang kurang dimanfaatkan. Kandungan lemak yang tinggi pada cangkang jambu mete sering diekstrak menjadi minyak laka (cashew nut shell liquid/CNSL) (Tyman 1975). Residu setelah ekstraksi lemak biasanya dibuang padahal residu ini masih dapat diolah. Saenab et al. (2016) telah mengembangkan tiga produk bioindustri dari cangkang jambu mete dan diantaranya biosmoke atau asap cair. Produk baru ini perlu dieksplorasi manfaatnya untuk bidang peternakan. Oleh sebab itu, penelitian ini bertujuan untuk membandingkan kemampuan asap cair cangkang jambu mete, tongkol jagung dan tempurung kelapa untuk menghambat pertumbuhan Escherichia coli dan Candida utilis.

\section{MATERI DAN METODE}

Cangkang mete diperoleh dari Pati, asap cair tongkol jagung (ACJ) diperoleh dari Laboratorium Residu Bahan Agrokimia, Laladon, Bogor, asap cair tempurung kelapa (ACK) diambil dari industri kecil di Cinangneng, Bogor. Pembuatan asap cair dilakukan menurut prosedur Sari et al. (2009) yang dilakukan di industri kecil di Cinangneng, Bogor. Sebelum proses pembuatan asap cair cangkang jambu mete (ACM), dilakukan perendaman dalam larutan heksana lebih dahulu dengan perbandingan 1:2 semalaman dengan ukuran 0,5-1 cm, ditiriskan, direndam kembali dengan heksana dengan perbandingan yang sama. Ditiriskan kembali, lalu diangin-anginkan semalaman untuk membuang heksana tersebut. Residu yang sudah kering digiling untuk mendapatkan ukuran yang lebih kecil untuk mempermudah pengeluaran zat bioaktif di dalamnya. Residu dimasukkan ke dalam drum, kemudian dibakar. Selama pembakaran terbentuk asap yang dikondensasi sehingga menjadi cairan pekat berwarna cokelat kehitaman dan ditampung di dalam botol. Larutan ini disebut asap cair cangkang jambu mete (ACM). Proses pembuatan ACJ dan ACK lebih mudah. Baik tongkol jagung ataupun tempurung kelapa tidak perlu diekstrak terlebih dahulu tetapi langsung dimasukkan dalam tong drum metal, kemudian dibakar seperti pada proses pirolisis residu cangkang jambu mete. 


\section{Uji antibakteri asap cair}

\section{Persiapan larutan, media dan kultur bakteri}

Media nutrient broth (NB) dibuat dengan campuran 1,3 g NB dan $100 \mathrm{ml}$ akuades, disterilkan dalam autoclave selama 10 menit pada suhu $115^{\circ} \mathrm{C}$. Perbanyakan bakteri E. coli ditumbuhkan pada media NB di dalam tabung reaksi bertutup dan diinkubasi pada suhu $37^{\circ} \mathrm{C}$ selama 24 jam.

\section{Uji penghambatan E. coli}

Uji antibakteri dilakukan dengan metode mikrodilusi pada microtiterplate flat-bottom polystyrene 96 wells. Pembacaan optical density (OD) dengan microplate reader (O'Toole \& Kolter 1998) pada panjang gelombang $620 \mathrm{~nm}$ di Laboratorium Teknologi Pakan, Balitnak. Jumlah E. coli yang akan digunakan adalah $10^{8} \mathrm{cfu} / \mathrm{ml}$ untuk dimasukkan ke tiap well. Oleh sebab itu, kultur yang mengandung E. coli diukur dan diatur kekeruhannya agar absorbansi kultur sebesar 0,138 (konsentrasi bakteri $10^{8} \mathrm{cfu} / \mathrm{ml}$ ). Pengukuran absorbansi dilakukan dengan alat spektrofotometer dengan panjang gelombang $620 \mathrm{~nm}$. ACM, ACJ dan ACK disaring dengan menggunakan membran filter ukuran pori $0,45 \mu \mathrm{m}$. Hasil penyaringan sampel dipindahkan ke tabung baru. Sampel asap cair diencerkan dengan komposisi: (1) Blanko: $20 \mu \mathrm{l}$ akuades $+180 \mu \mathrm{l}$ media NB; (2) Blanko ekstrak: $20 \mu \mathrm{l}$ asap cair $+180 \mu 1$ media NB; (3) Kontrol negatif: $20 \mu$ l akuades $+180 \mu 1$ kultur E. coli; dan (4) Asap cair: $20 \mu \mathrm{l}$ ACM/ACJ/ACK $+180 \mu \mathrm{l}$ kultur E. coli.

Tabel 1. Pengenceran sampel ACM, ACJ dan ACK

\begin{tabular}{lccc}
\hline \hline Larutan & Pengenceran & Larutan awal $(\mu \mathrm{l})$ & Akuades $(\mu \mathrm{l})$ \\
\hline Asap cair & 4 kali $(2,5 \%)$ & 400 & 1.200 \\
Asap cair & 8 kali $(1,25 \%)$ & 200 & 1.400 \\
Asap cair & 16 kali $(0,625 \%)$ & 100 & 1.500 \\
\hline
\end{tabular}

Kemudian sampel ACM, ACJ, ACK, blanko dan kontrol masing-masing 4 wells dimasukkan ke dalam microplate yang terdiri dari 96 well (Gambar 1) dengan perlakuan/komposisi microplate yang sudah diisi blanko, blanko ekstrak, kontrol negatif dan ACM/ACJ/ACK diinkubasi semalaman pada suhu $37^{\circ} \mathrm{C}$, selanjutnya diukur dengan menggunakan microplate reader pada panjang gelombang $620 \mathrm{~nm}$. Setiap perlakuan dibuat empat lubang sumuran berupa ulangan.

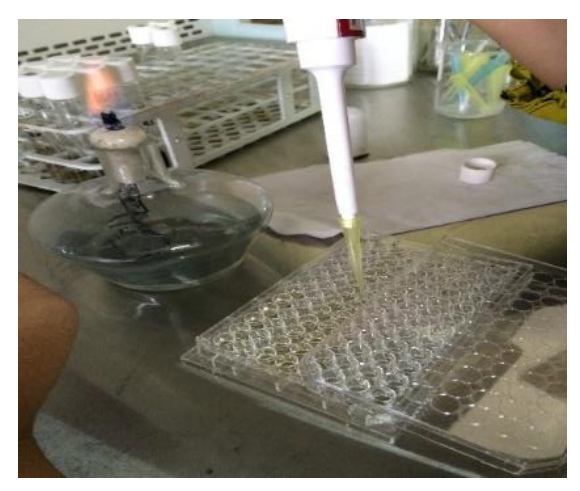

Gambar 1. Microplate reader (96 wells/lubang sumuran) diisi dan disesuaikan dengan perlakuan

Perhitungan pertumbuhan mikroba:

Pertumbuhan mikroba $=($ Absorbansi mikroba/absorpansi kontrol $) \times 100 \%$ 


\section{HASIL DAN PEMBAHASAN}

ACM dan ACJ menunjukkan kemampuan yang lebih tinggi untuk menghambat pertumbuhan E. coli dibandingkan dengan ACK (Tabel 1). Hal ini menunjukkan bahwa jumlah senyawa fenol dalam tanaman berpengaruh terhadap penghambatan pertumbuhan E. coli. Hal ini dibuktikan dari jumlah senyawa fenol yang terdapat dalam ACM lebih tinggi (7,2\%) dibandingkan dengan ACJ (6,73\%) dan ACK (5,47\%) (Saenab et al. 2016; Reta \& Anggraeni 2016). Namun demikian, tempurung kelapa masih mampu menghambat pertumbuhan E. coli walaupun dalam jumlah lebih kecil. Swastawati et al. (2014) melaporkan bahwa senyawa fenol dapat menghambat pertumbuhan E. coli, Staphylococcus aureus, Vibrio harveyi dan Vibrio parahaemolyticus. Hambatan pertumbuhan C. utilis didominasi oleh ACJ dan ACK dibandingkan dengan ACM, walaupun kandungan fenol ACM sedikit lebih tinggi. Sementara ACK dapat menghambat pertumbuhan Pseudomonas aeruginosa dan S. aureus (Zuraida et al. 2011). Swastawati et al. (2014) melaporkan asap cair tongkol jagung efektif menghambat pertumbuhan mikroba patogen seperti E. coli, $S$. aureus, $V$. harveyi dan $V$. parahaemolyticus.

Tabel 1. Kadar $\mathrm{pH}$ dan persentase daya hambat pertumbuhan E. coli dan $C$. utilis pada tiga jenis asap cair

\begin{tabular}{lccc}
\hline \hline Asap cair & $\mathrm{pH}$ & E. coli $(\%)$ & C. utilis $(\%)$ \\
\hline Kontrol & 7,00 & 100 & 100 \\
ACM (jambu mete) & 3,12 & 80,85 & 23,88 \\
ACJ (jagung) & 4,22 & 72,34 & 97,17 \\
ACK (tempurung kelapa) & 3,07 & 38,30 & 86,80 \\
\hline
\end{tabular}

Mekanisme zat bioaktif menghambat pertumbuhan bakteri adalah dengan cara merusak sitoplasma, DNA atau inti sel dari bakteri. Fenol dengan gugus $-\mathrm{OH}$ nya dapat melarutkan lipid pada dinding sel, akibatnya mengganggu kinerja membran sitoplasma dan menghambat ikatan ATP-ase yang menyebabkan sel menjadi lisis, akibatnya pertumbuhan bakteri terhambat (Turgis et al. 2009).

Mekanisme zat bioaktif (asam fenolik berupa asam kafeat dan derivatnya) menghambat perkembangan jamur $C$. utilis dengan cara menghambat praformasi biofilm, merusak dinding sel, mengganggu plasma membran, menghambat dimorfisme dan menghambat aktivitas enzim (Sung \& Lee 2010; Ma et al. 2010; Alves et al. 2014; Cheah et al. 2014).

\section{Pengaruh derajat keasaman terhadap pertumbuhan mikroba}

Kemampuan mikroba untuk tumbuh dipengaruhi faktor intrinsik $(\mathrm{pH}$, aktivitas air, potensial oksidasi-reduksi, kandungan nutrisi, kandungan senyawa antimikroba dan struktur biologi) dan faktor ekstrinsik (suhu, kelembaban lingkungan dan susunan gas lingkungan). Pada umumnya, mikroba berkembang dengan baik pada $\mathrm{pH}$ netral $(6,6-6,7)$. Bakteri negatif $E$. coli tumbuh baik pada pH 6-7, tapi masih bisa tumbuh pada pH 9 (Pelczar \& Chan 1988).

Pada Tabel 1 ditunjukkan bahwa pH dari ACM, ACJ dan ACK di bawah angka 7, hal ini menunjukkan bahwa bakteri tidak punya peluang untuk berkembang. Artinya, ACM, ACJ dan ACK mampu menghambat pertumbuhan E. coli. Demikian juga pengaruh ketiga asap cair tersebut, dengan derajat keasaman yang rendah dapat menghambat pertumbuhan 
fungi $C$. utilis. Namun demikian, $\mathrm{pH}$ yg makin rendah tidak terlalu berpengaruh terhadap pertumbuhan C. utilis (Boze et al. 1992).

\section{Pengaruh dosis ACM, ACJ dan ACK terhadap pertumbuhan C. utilis}

Gambar 2 menunjukkan pada ketiga asap cair, pengenceran yang semakin tinggi menyebabkan pertumbuhan $C$. utilis yang makin tinggi juga. Hal ini membuktikan bahwa zat bioaktif fenol yang terkandung dalam asap cair yang dengan pengenceran yang semakin tinggi maka kandungan fenolnya semakin rendah. Pengenceran hingga 16 kali pada pada ACM, ACJ dan ACK mempunyai daya hambat pada pertumbuhan C. utilis berturut-turut 10,37; 67,87; dan 57,32\%. Hal ini menunjukkan ACJ lebih efektif mencegah pertumbuhan $C$. utilis. Kandungan fenol pada asap cair mampu menghambat perkembangan $C$. utilis. Cleff et al. (2010) melaporkan, aktivitas antifungi Origanum vulgare dengan kandungan 4-terpineol $(47,95 \%)$ mampu menghambat pertumbuhan Candida sp.

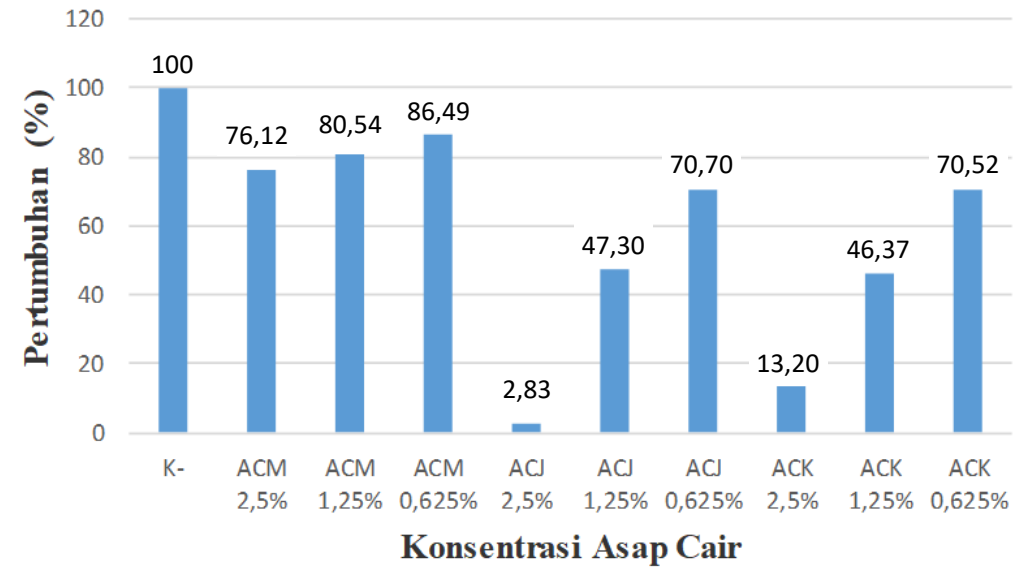

Gambar 2. Pengaruh dosis ACM, ACJ dan ACK terhadap pertumbuhan C. utilis

\section{Korelasi antara total fenol dengan penghambatan $C$. utilis}

Gambar 3 menunjukkan semakin tinggi kandungan fenol maka daya hambat fenol dari ACM, ACJ, ACK semakin tinggi pula. Hal ini mengindikasikan fenol memiliki peranan dalam menghambat pertumbuhan C. utilis. Hal ini dibuktikan pada pengenceran dari ketiga jenis asap cair (Gambar 1). Semakin encer asap cair maka pertumbuhan C. utilis semakin naik. Cleff et al. (2010) melaporkan bahwa fenol yang terdapat dalam Oregano vulgare dapat digunakan sebagai antifungi, Daging buah, kulit buah, Punica granatum L mampu menghambat pertumbuhan genus Candida termasuk C. utilis (Anibal et al. 2013). 


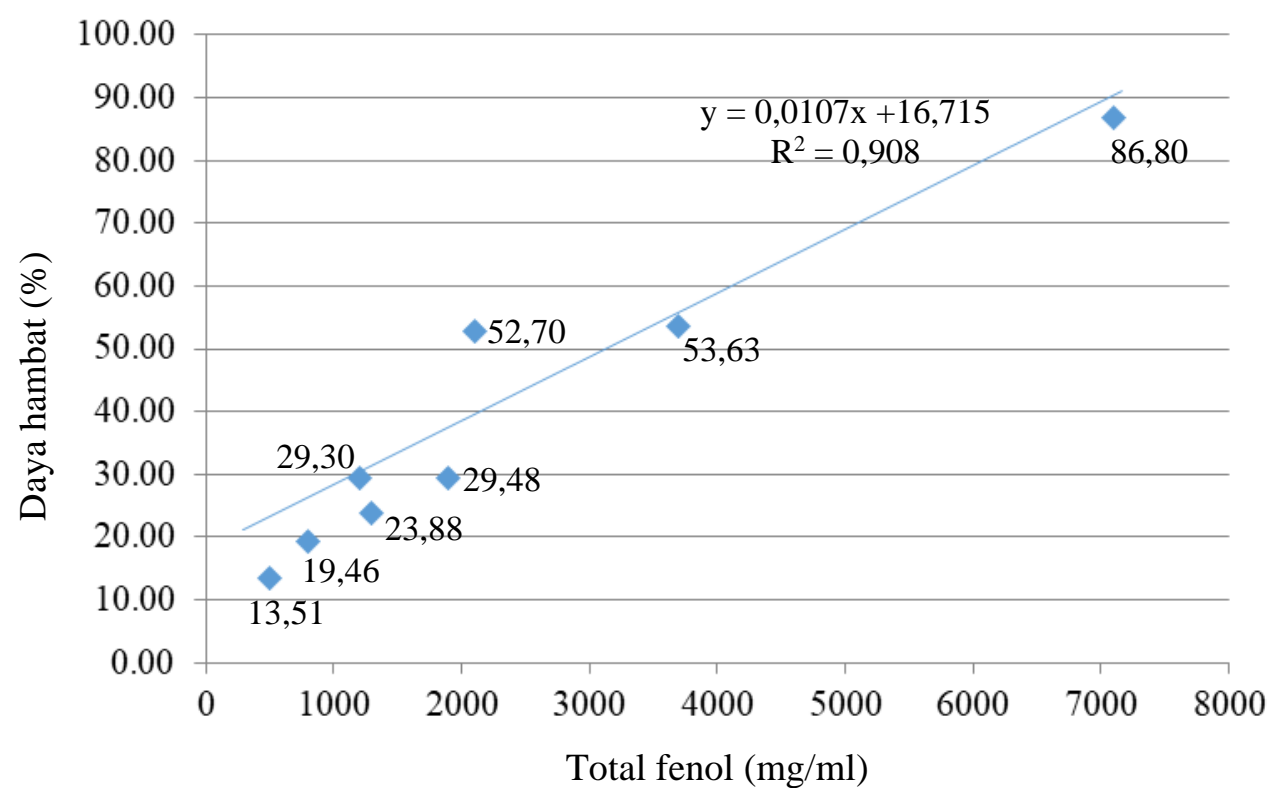

Gambar 3. Korelasi antara total fenol dengan penghambatan C. utilis

\section{KESIMPULAN}

Asap cair sumber cangkang mete (ACM) dan tongkol jagung (ACJ) lebih efisien menghambat pertumbuhan E. coli. ACJ dan ACK (asap cair sumber tempurung kelapa) lebih efisien menghambat pertumbuhan $C$. utilis. Semakin tinggi kandungan fenol ACM, ACJ dan ACK maka daya hambat pada $C$. utilis semakin meningkat. Disimpulkan bahwa ACM, ACJ dan ACK dapat menekan pertumbuhan bakteri E. coli dan fungi $C$. utilis sehingga punya potensi sebagai antimikroba dalam pemanfaatannya pada unggas.

\section{DAFTAR PUSTAKA}

Alves CT, Ferreira IC, Barros L, Silva S, Azeredo J, Henriques M. 2014. Antifungal activity of phenolic compounds identified in flowers from North Eastern Portugal against Candida species. Future Microbiol. 9:139-146.

Anibal PC, Peixoto ITA, Mary Ann Foglio MA, Höfling JF. 2013. Antifungal activity of the ethanolic extracts of Punica granatum L and evaluation of the morphological and structural modifications of its compounds upon the cells of Candida spp. Braz J Microbiol. 44:839-848.

Boze H, Moulin G, Galzy P. 1992. Production of food and fodder yeasts. Crit Rev Biotechnol $12: 65-86$.

Cheah HL, Lim V, Sandai D. 2014. Inhibitors of the glyoxylate cycle enzyme ICL1 in Candida albicans for potential use as antifungal agents. PLoSONE. 9:1-8.

Cleff MB, Meinerz AR, Xavier M, Schuch LF, Meireles MCA, Rodrigues MRA, de Mello JRB. 2010. In vitro activity of Origanum vulgare essential oil against Candida species. Braz J Microbiol. 41:116-123.

Darmadji P. 2002. Optimasi pemurnian asap cair dengan metode redistilasi. J Teknologi Industri Pangan. 13:267-271.

Girrard JP. 1992. Smoking in technology of meat products. New York (US): Clermont Ferrand. Ellis Horwood. p. 165:205. 
Lingbeck JM, Cordero P, O’Bryan CA, Johnson MG, Ricke SC, Crandall PG. 2014. Functionality of liquid smoke as an all-natural antimicrobial in food preservation. Meat Sci. 97:197-206.

Ma CM, Abe T, Komiyama T, Wang W, Hattori M, Daneshtalab M. 2010. Synthesis, anti-fungal and 1,3-beta-D-glucan synthase inhibitory activities of caffeic and quinic acid derivatives. Bioorg Med Chem. 18:7009-7014.

O'Toole G, Kolter R. 1998, Initiation of biofilm formation in Pseudomonas fluorescens WCS365 proceeds via multiple, convergent signaling pathways: A genetic analysis, molecular. Microbiology. 28:449-461.

Pelczar MZ, Chan ECS. 1988. Dasar-dasar mikrobiologi. Jilid II. Jakarta (Indonesia): UI Press.

Rasydta HP. 2013. Penggunaan asap cair tempurung kelapa dalam pengawetan ikan bandeng. [Tesis].[Semarang (Indonesia): Universitas Negeri Semarang].

Reta KB, Anggraini SPA. 2016. Pembuatan asap cair dari tempurung kelapa, tongkol jagung dan bamboo menggunakan proses slow pyrolysis. Reka Buana. 14.

Saenab A, Komang GW, Retnani Y, Wina E. 2016. Karakteristik sifat fisik dan kimia cangkang jambu mete. J Littri. 22:35-41.

Sari TI, Amalia KA, Rahmawati. 2009. Proses pembuatan asap cair (liquid smoke) dari limbah industri. J Teknik Kimia. 2:44-47.

Sari ML, Lubis FNL, Jaya LD. 2014. Pengaruh pemberian asap cair melalui air minum terhadap kualitas karkas ayam broiler. J Agripet 14(1): 71-75.

Sung WS, Lee DG. 2010. Antifungal action of chlorogenic acid against pathogenic fungi, mediated by membrane disruption. Pure Appl Chem. 82:219-226.

Swastawati F, Boesono SH, Wijayanto D. 2014. Antimicrobial activity of corncob liquid smoke and its aplication to smoked milkfish (Chanos chanos Forsk) using electric and mechanical oven. 2014. In: Int Conference on Food Sec and Nut IPCBEE. Singapore (Singapore): IACSIT Press.

Turgis M, Han J, Caillet S, Lacroix M. 2009. Antimicrobial activity of mustard essential oil against Escherichia coli O157:H7 and Salmonella typhi. Food Control. 20:1073-1079.

Tyman JHP. 1975. Quantitative determination of the olefinic composision of the component phenols in cashew nut shell liquid. J Chrom. 3:P277-284.

Wang SS, Wang DM, Pu WJ, Li DW. 2013. Phytochemical profiles, antioxidant and antimicrobial activities of three Potentilla sp BMC complement altern. Medicine. 13:1-11.

Yosi F, Sandi S. 2014. Pemanfaatan asap cair sebagai bahan aditif dan implikasinya terhadap sistem imun dan mortalitas ayam broiler. J Peternakan Sriwijaya. 3(2): 28-34.

Zuraida I, Sukarno, Budijanto S. 2011. Antibacterial activity of coconut shell liquid smoke (CSLS) and its application on fish ball preservation. Int Food Res J. 18:405-410. 